\title{
Editorial
}

\section{Diabetes in India: a long way to go}

\author{
Monica Gupta*, Ram Singh, S. S. Lehl
}

Department of Medicine, Government Medical College and Hospital, Chandigarh, India

\author{
*Correspondence: \\ Dr. Monica Gupta, \\ E-mail: drmg1156@gmail.com
}

Copyright: (C) the author(s), publisher and licensee Medip Academy. This is an open-access article distributed under the terms of the Creative Commons Attribution Non-Commercial License, which permits unrestricted non-commercial use, distribution, and reproduction in any medium, provided the original work is properly cited.

Diabetes mellitus, a major lifestyle disease is undoubtedly the most challenging public health problem of $21^{\text {st }}$ century with a worldwide prevalence of 387 million $(8.3 \%)$ and predicted to be 592 million by 2035 . $^{1,2}$ $77 \%$ of people with diabetes live in low- and middleincome countries. India, once known as the 'diabetes capital of the world' was home to 61.3 million patients with T2DM in 2011 with predictions of 101.2 million diabetics by $2030 .{ }^{1,3}$ India is second only to China which is home to 92.3 million diabetics. The International Diabetes Federation estimated a doubling of diabetic population between 1995 and 2005, and predicted 70 million diabetics by $2025{ }^{4}$

The overall crude prevalence of diabetes using WHO criteria in CURES was 15.5 per cent while that of IGT was 10.6 per cent. ${ }^{5}$ The WHO-ICMR national NCD risk factor surveillance study reported an overall frequency of self-reported diabetes of $4.5 \%$ with urban population scoring higher $(7.3 \%)$, over the rural areas $(3.1 \%) .{ }^{6}$ These studies also reported three-fold higher (18.9/1000 personyears) mortality in diabetes compared to non-diabetic $(5.3 / 1000$ person-years, $\mathrm{p}=0.004)$. The World Health Organization predicted a $50 \%$ increase in deaths from diabetes over next 10 years, and by 2030, diabetes is projected to be the seventh leading cause of death. ${ }^{7}$ Although worrisome statistics, considering the inherent variability in biological phenomenon and widespread interventions for control of disease, these estimated extrapolations and predictions may prove tentative in relation to the potential burden that diabetes may impose upon the country.

Indians have a peculiar genetic composition and Asian Indian phenotype that predisposes them to have higher propensity to metabolic syndrome, diabetes mellitus and coronary artery disease. Indians characteristically have increased insulin resistance, greater abdominal adiposity (higher waist circumference despite lower body mass index), higher prevalence of impaired glucose tolerance, lower adiponectin and higher high sensitive C-reactive protein levels; contributing to a greater risk of developing disease at a relatively younger age. ${ }^{8}$ Additionally epidemiological transition, economic boom, physical inactivity, trendy dietary patterns and environmental factors also add to this risk.

Indian healthcare professionals and patients in India face a number of challenges such as clinical inertia in achieving glycemic control, inadequate follow-up and lack of disease awareness. ${ }^{9}$ Various studies have reported that Indian patients with T2DM fail to achieve treatment targets and have higher mean $\mathrm{HbA} 1 \mathrm{C}$ indicating poor glycemic control. ${ }^{10,11}$ While HbA1c is the gold standard test for measuring glycemic control, it is not readily available. An inadequacy in Indian guidelines is also responsible for wide variation in treatment preferences across the country. ${ }^{12}$

The current scenario of diabetes in India is likely to worsen in the coming decade. The greatest numbers of people with diabetes are between 40 and 59 years of age. High prevalence of obesity in Indian adolescents may aggravate the situation. ${ }^{13}$ The most disturbing trend is the shift in age of onset of diabetes to a younger age in the recent years. ${ }^{14}$ The recent trend of rising diabetes among rural Indians and women is also alarming. Even though the prevalence of microvascular complications of diabetes like retinopathy and nephropathy are comparatively lower in Indians, premature coronary artery disease is much higher in Indians compared to other ethnic groups. Given the lifelong costs associated with diabetes, many individuals and families are unable to cope with the economic, emotional and social disease burden.

Early identification of at-risk individuals and appropriate lifestyle intervention would significantly help in preventing or postponing the onset of diabetes. Awareness, education, and empowerment of community 
could prevent a cluster of non-communicable disorders, an exemplary effort in this direction is the Prevention Awareness Counseling and Evaluation (PACE) Diabetes programme underway in Chennai. ${ }^{15}$ As a matter of fact, CURES has already shown some degree of leveling of the predicted prevalence line, evidenced by the fact that the prevalence of diabetes in Chennai showed a rise of $39.8 \%$ between 1989-1995, 16.3\% between 1995-2000 and $6 \%$ between the year 2000-2004. ${ }^{13}$

Yet, a lot needs to be done. There is an imminent need for urgent contextual research and implementing inexpensive intervention with sincere efforts at regional and national levels to mitigate the potentially catastrophic increase in diabetes that is predicted for the upcoming years.

\section{REFERENCES}

1. International Diabetes Federation. IDF diabetes atlas. In: IDF, eds. A Book. 6th ed. Brussels, Belgium: International Diabetes Federation; 2013.

2. Kaveeshwar SA, Cornwall J. The current state of diabetes mellitus in India. Australas Med J. 2014;7:45-8.

3. Mohan V, Madan Z, Jha R, Deepa R, Pradeepa R. Diabetes social and economic perspectives in the new Millennium. Int $\mathrm{J}$ Diab Dev Countries. 2004;24:29-35.

4. International Diabetes Federation. IDF diabetes atlas. In: IDF, eds. A Book. 6th ed. 4th ed. Brussels, Belgium: International Diabetes Federation; 2009.

5. Ramachandran A, Snehalatha C, Kapur A, Vijay V, MohanV, Das AK, et al. Diabetes Epidemiology Study Group in India (DESI). High prevalence of diabetes and impaired glucose tolerance in India: National Urban Diabetes Survey. Diabetologia. 2001;44:1094-101.

6. Global Forum Health. Risk factor surveillance for non-communicable diseases (NCDs): the multi-site ICMR-WHO collaborative initiative, 2015. Available at: http://www.globalforumhealth.org/.

7. World Health Organization. 10 facts about diabetes, 2013. Available at: http://www.who.int/features/factfiles/diabetes/en/.
8. Radha V, Mohan V. Genetic predisposition to type 2 diabetes among Asian Indians. Indian $\mathbf{J}$ Med Res. 2007;125(3):259-74.

9. Joshi SR, Das AK, Vijay VJ, Mohan V. Challenges in diabetes care in India: sheer numbers, lack of awareness and inadequate control. J Assoc Physicians India. 2008;56:443-50.

10. Moses CR, Seshiah V, Sahay BK, Kumar A, Asirvatham AJ, Balaji V, et al. Baseline results indicate poor glycemic control and delay in initiation and optimization of insulin therapy: results from the improving management practices and clinical outcomes in type 2 diabetes study. Indian J Endocrinol Metab. 2012;16(Suppl 2):S432-3.

11. Inzucchi SE, Bergenstal RM, Buse JB, Diamant M, Ferrannini E, Nauck M, et al. American Diabetes Association (ADA); European Association for the Study of Diabetes (EASD). Management of hyperglycemia in type 2 diabetes: a patient-centered approach: position statement of the American Diabetes Association (ADA) and the European Association for the Study of Diabetes (EASD). Diabetes Care. 2012;35(6):1364-79.

12. Unnikrishnan RI, Anjana RM, Mohan V. Importance of controlling diabetes early-The concept of metabolic memory, legacy effect and the case for early insulinisation. J Assoc Physicians India. 2011;59(Suppl):8-12.

13. Misra A, Vikram NK, Arya S, Pandey RM, Dhingra $\mathrm{V}$, Chattergee A, et al. High prevalence of insulin resistance in postpubertal Asian Indian children is associated with adverse truncal body fat patterning, abdominal adiposity and excess body fat. Int J Obes. 2004;28:1217-26.

14. Mohan V, Deepa M, Deepa R, Shantirani CS, Farooq S, Ganesan A, et al. Secular trends in the prevalence of diabetes and glucose tolerance in urban South India - the Chennai Urban Rural Epidemiology Study (CURES-17). Diabetologia. 2006;49:1175-8.

15. Suresh S, Deepa R, Pradeepa R, Rema M, Mohan V. Large-scale diabetes awareness and prevention in South India. Diabetes Voice. 2005;50:11-4.

Cite this article as: Gupta M, Singh R, Lehl SS. Diabetes in India: a long way to go. Int J Sci Rep 2015;1(1):1-2. 